\title{
PERANCANGAN SISTEM INFORMASI PENGAJUAN PINJAMAN BERBASIS WEB MENGGUNAKAN METODE SIMPLE ADDITIVE WEIGHTING
}

\author{
Titis Widyastuti; Nia Rahma Kurnianda² \\ Program Studi Sistem Informasi \\ Universitas Mercu Buana \\ www.mercubuana.ac.id \\ 141815010106@student.mercubuana.ac.id,2nia.rahma@mercubuana.ac.id
}

\begin{abstract}
In an effort to increase the number of members who join in the shade of cooperative employees, UMB cooperative intends to improve services for savings and loan products. However these products have a very long service life span and a large queue. Before the loan is approved there is file verification on the member application first.Data collection and recording of loans and loan repayments are still carried out simply by handwriting method. This causes vulnerability to human error and uncontrolled documents. Therefore, we designed an information system for loan applications for members to resolve these problems. To support the efforts of employee cooperatives to make it easy to apply for loans, this design is made on a web and object oriented basis.This system will make it easier for members to apply for loans from anywhere and at any time, providing flexibility for members to know the status of the loan proposed and the return of the debt that has been paid. In addition, from the perspective of $U M B$ employee cooperatives, the benefits received are convenience and speed in terms of file verification and the administration of loan lending. In addition, in making reports, it is also a major feature of the system that we designed. In producing approved loan recommendations we use a variety of SAW methods. The results of the calculation of this recommendation feature will be the basis for faster file verification services.
\end{abstract}

Keywords: Cooperatives, Information Systems, SAW.

Intisari-Dalam usaha meningkatkan jumlah anggota yang bergabung dalam naungan koperasi karyawan, koperasi UMB bermaksud melakukan peningkatan pelayanan pada produk simpan pinjam. Namun produk tersebut memiliki rentang waktu pelayanan yang sangat panjang dan antrian yang cukup besar.Sebelum peminjaman disetujuiterdapat verifikasi berkas atas aplikasi anggota terlebih dahulu.Pendataan dan pencatatan atas peminjaman dan pembayaran pinjaman pun masih dilakukan secara sederhana yaitu dengan metode tulis tangan.Hal ini menyebabkan rawan terjadinya human error dan dokumen tidak terkontrol.Oleh karena itu, kami merancang sebuah sistem informasi pengajuan pinjaman bagi anggota untuk menyelesaikan permasalahan tersebut.Untuk mendukung usaha koperasi karyawan memberikan kemudahan dalam mengajukan pinjaman, rancangan ini kami buat menggunakan basis web dan berorientasi obyek. Sistem ini nantinya akan memberikan kemudahan bagi anggota untuk mengajukan pinjaman dari manapun dan kapanpun, memberikan keleluasaan bagi anggota untuk mengetahui status peminjaman yang diajukan dan pengembalian hutang yang telah dibayarkan. Selain itu dari sisi koperasi pegawai UMB, benefit yang diterima adalah kemudahan dan kecepatan dalam hal verifikasi berkas serta kerapihan administrasi peminjaman uang. Selain itu dalam pembuatan laporan juga menjadi fitur utama dari sistem yang kami rancang ini. Dalam menghasilkan rekomendasi peminjaman yang disetujui kami menggunakan variasi metode SAW. Hasil kalkulasi dari fitur rekomendasi ini akan menjadi dasar bagi pelayanan verifikasi berkas yang lebih cepat.

Kata Kunci: Koperasi, Sistem Informasi, SAW.

\section{PENDAHULUAN}

Teknologi adalah hal yang penting dalam memajukan infrasturktur pada sebuah perusahaan. Dengan adanya teknologi, perusahaan dapat terbantu serta memudahkan dalam menjalankan usahanya. Pada era modern seperti ini koperasi harus memaksimalkan penggunaan teknologi untuk memudahkan pekerjaan para karyawan koperasi dalam memanajement data.Koperasi karyawan adalah sebuah badan usaha yang bersifat sosial dan merakyat yang berlokasi pada perusahan yang beranggota karyawan perusahaan (Subiantara, Sulistiowati, \& Vivine, 2015). Tujuan didirikannya koperasi karyawan yaitu untuk meningkatkan kesejahteraan para karyawan. Koperasi merupakan usaha yang banyak 
melakukan transaksi administrasi, maka komputerisasi dalam bidang administrasi sangatlah penting guna menunjang kelancaran seluruh transaksi yang dilakukan oleh koperasi sehingga dapat memberikan pelayanan transaksi dengan cepat, tepat, dan akurat (Waluya \& Dimas, 2017).

Koperasi karyawan Universitas Mercu Buana adalah koperasi untuk para karyawan yang bekerja didalamnya, jumlah anggota yang bergabung pada saat ini sebanyak 300 anggota. Dengan jumlah anggota yang cukup banyak berkemungkinan nantinya akan bertambah setiap tahunya, maka diperlukan manajemen data yang baik.Dalam usaha meningkatkan jumlah anggota yang bergabung dalam naungan koperasi karyawan, koperasi UMB bermaksud melakukan peningkatan pelayanan pada produk simpan pinjam. Namun produk tersebut memiliki rentang waktu pelayanan yang sangat panjang dan antrian yang cukup besar. Sebelum peminjaman disetujui terdapat verifikasi berkas atas aplikasi anggota terlebih dahulu. Dari hasil wawancara yang penulis lakukan, pendataan dan pencatatan atas peminjaman dan pembayaran pinjaman pun masih dilakukan secara sederhana yaitu dengan metode tulis tangan, hal ini memungkinkan terjadinya inkonsistensi dan redudansi data (Astuti \& Devitra, 2017).

Untuk anggota yang ingin mengajukan pinjaman atau mendaftar menjadi anggota koperasi, anggota diminta mengisi formulir kertas dimana formulir yang telah diisi sering hilangkarena tidak ditempatkan pada penyimpanan yang baik dan itu kurang efektif yang mengakibatkan proses pengajuan pinjaman tergangu dan mengecewakan anggota, serta untuk menentukan anggota yang berhak menerima pinjaman, koperasi kesulitan dalam mencari history data pinjaman anggota. Karena dalam menentukan apakah anggota berhak menerima pinjaman selain melihat dari gaji bersih koperasi juga melihat dari history pinjaman anggota (Subiantara et al., 2015).

Dari permasalahan tersebut koperasi karyawan Universitas Mercu Buana ingin membuat sistem yang terkomputerisas sehingga proses pengajuan pinjaman menjadi tepat waktu, dan efisien (Journal, Utomo, \& Ipmawati, 2016). Oleh karena itu, kami merancang sebuah sistem informasi pengajuan pinjaman bagi anggota untuk menyelesaikan permasalahan tersebut. Untuk mendukung usaha koperasi karyawan memberikan kemudahan dalam mengajukan pinjaman, rancangan ini kami buat menggunakan basis web dan berorientasi obyek. Sistem ini nantinya akan memberikan kemudahan bagi anggota untuk mengajukan pinjaman dari manapun dan kapanpun, memberikan keleluasaan bagi anggota untuk mengetahui status peminjaman yang diajukan dan pengembalian hutang yang telah dibayarkan. Selain itu dari sisi koperasi pegawai UMB, benefit yang diterima adalah kemudahan dan kecepatan dalam hal verifikasi berkas serta kerapihan administrasi peminjaman uang. Selain itu dalam pembuatan laporan juga menjadi fitur utama dari sistem yang kami rancang ini.

Dalam menghasilkan rekomendasi peminjaman yang disetujui kami menggunakan variasi metode SAW. Metode Simple Additive Weighting (SAW) merupakan sebuah metode penjumlahan yang berbobot dari rating pada setiap (Wati \& Sadikin, 2019). Metode Simple Additive Weighting (SAW) membutuhkan proses normalisasi matriks keputusan (X) kesuatu skala yang dapat diperbandingkan dengan semua rating alternatif yang ada. Metode ini merupakan metode yang paling banyak digunakan dalam menghadapi situasi Multiple Atribute Decision Making (MADM)(Christin, Djamain, Informatika, \& Informatika, 2015). Hasil kalkulasi dari fitur rekomendasi ini akan menjadi dasar bagi pelayanan verifikasi berkas yang lebih cepat.

\section{BAHAN DAN METODE}

\section{Metode Pengumpulan Data}

Dalam membangun sistem informasi koperasi berbasis website harus adanya penelitian yang dilakuakan agar dapat terlaksana dengan baik, metode dalam penelitian tersebut yaitu melakukan wawancara dengan ketua koperasi yaitu Bpk Anwar, wawancara dilakukan untuk mendapatkan alur proses bisnis, knowledge, dan aturan-aturan terkaitsistem yang dibangun dari pihak yang terkait sehingga pembangunan system sesuai dengan kebutuhan dan dapat menjadi solusi yang tepat. Observasi dilakukan dengan turun langsung dan membantu mengerjakan proses bisnis secara langsung dan pengumpulan data dilakukan dengan datang dan melihat proses pengajuan pinjaman, proses persetujuan pinjaman, pengelolan data pinjaman dan pendaftaran anggota di koperasi karyawan UMB.Pada studi kepustakaan penulisan dilakukan dengan cara mencari bahan yang mendukung dalam pendefinisian permasalahan melalui buku-buku, jurnal-jurnal yang erat kaitannya dengan objek permasalahan.

\section{Metode Seleksi Berkas Pengajuan Pinjaman Menggunakan Metode SAW}

Dalam penelitian ini metode SAW digunakan untuk pengajuan pinjaman disetujui atau tidak hasil akhir berupa rekomendasi pinjaman yang disetujui. Adapun langkah-langkah SAW yang 
digunakan dalam menghasilkan rekomendasi peminjaman yang disetujui antara lain :

a. Menentukan alternatif

b. Menentukan kriteria yang akan dijadikan acuan dalam pengambilan keputusan

c. Menentukan nilai rating kecocokan setiap alternatif pada setiap kriteria.

d. Menentukan bobot preferensi atau tingkat kepentingan pada setiap kriteria

e. Membuat tabel rating kecocokan dari setiap alternatif pada setiap kriteria.

f. Membuat matriks keputusan (X) yang dibentuk dari tabel rating kecocokan dari setiap alternatif pada setiap criteria.

g. Melakukan normalisasi matriks keputusan dengan cara menghitung nilai rating kinerja ternomalisasi (rij) dari alternative pada kriteria berdasarkan rumus di bawah ini :

$$
r_{i}=\left\{\begin{array}{c}
\frac{x_{i j}}{\operatorname{Maxx_{ij}} \text { Jikajatributkeuntungan(benefit) }} \\
\frac{\text { Minx } x_{i j}}{x_{i j}} \text { Jikajatributbiaya(cost) }
\end{array}\right.
$$

Keterangan :

- Jika j adalah atribut biaya (cost)

- Jika j adalah atribut keuntungan (benefit)

- $\quad$ rij = rating kerja ternormalisasi.

- $\operatorname{Max}=$ nilai maksimum dari setiap baris dan kolom.

- $\operatorname{Min}=$ nilai manimum dari setiap baris dan kolom.

h. Hasil dari nilai rating kinerja ternormalisasi (rij) membentuk matrik ternormalisasi (R).

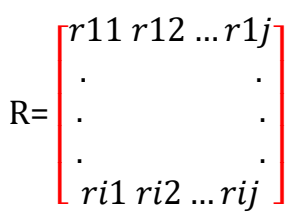

i. Hasil akhir nilai preferensi (Vi) diperoleh dari penjumlahan hasil perkalian elemen baris matrik ternormalisasi (R) dengan bobot preferensi (W) yang bersesuaian elemen kolom matrik $(\mathrm{W})$.

$V_{i}=\sum_{j=1}^{n} W_{j} r_{i j}$

Keteragan:

- $\quad \mathrm{Vi}=$ nilai akhir dari alternatif.

- $\mathrm{Wi}=$ bobot yang telah ditentukan.

- $\quad$ rij = normalisasi matriks

- Nilai Vi yang lebih besar mengindikasikan bahwa alternative lebih terpilih
Hasil perhitungan nilai Vi yang lebih besar mengindikasikan bahwa alternatif Ai merupakan alternatif terbaik (Saw, 2019).

\section{Metode Pengambilan Sample}

Pengambilan semple dilakukan dengan menggunakan metode purposive sampling pada proses pengajuan pinjaman di koperasi karyawan universitas mercu buana adapun contoh yang diambil yaitu pengajuan pinjaman uang dari salah satu anggota koperasi.

\section{Metode Analisa}

Pada perancangan suatu sistem diperlakukan analisa yang tepat, sehingga proses pembuatan sistem dapat berjalan dengan lancar dan sesuai seperti yang diinginkan (Rudiarto, 2018). Analisa yang dilakukan yaitu menggunakan Unified Moddeling Language (UML), dari semua UML yang digunakan hanya use case diagram, activity diagram, sequence diagram, dan class diagram.

\section{HASIL DAN PEMBAHASAN}

\section{Simulasi Sample Perangkingan Menggunakan Metode SAW}

Hasil studi kasusanalisa perancangan Simpple Additive Weighting, yaitu:

a. Menentukan alternatif,dalam contoh kali ini, kami mengambil 4 contoh pengajuan pinjaman dari empat anggota yang berbeda:

A1 = Anggota 1 (Alternatif 1 )

A2 = Anggota 2 (Alternatif 2)

A3 = Anggota 3 (Alternatif 3 )

A4 = Anggota 4 (Alternatif 4)

A1 sampai dengan A4 merupakan alternatif pemberian persetujuan pinjaman koperasi karyawan yang merupakan anggota koperasi tersebut.

b. Kriteria penilaian untuk penerimaan pinjaman berjumlah 7 kriteria, yaitu: jumlah pinjaman, gaji bersih, pinjaman uang kopkar, pinjaman barang kopkar, pinjaman bank, hutang toko, dan status kepegawaian yang diberi kode C1 sampai dengan C7.

c. Penilaian bobot untuk setiap kriteria diilustrasikan melalui tabel 1 dan dibawah ini dan nilai untuk setiap sub kriteria digambarkan melalui tabel 2, yaitu seperti dibawah ini :

Tabel 1. Tabel Kriteria

\begin{tabular}{lllll}
\hline No. & Kriteria & Keterangan & Bobot & Type \\
\hline 1. & C1 & Jumlah pinjaman & $25 \%$ & Benefit \\
\hline 2. & C2 & Gaji bersih & $30 \%$ & Benefit \\
\hline 3. & C3 & $\begin{array}{l}\text { Pinjaman uang } \\
\text { kopkar }\end{array}$ & $10 \%$ & Benefit \\
\hline 4. & C4 & $\begin{array}{l}\text { Pinjaman barang } \\
\text { kopkar }\end{array}$ & $10 \%$ & Benefit \\
\hline
\end{tabular}




\begin{tabular}{lllll}
\hline 5. & C5 & Pinjaman bank & $15 \%$ & Benefit \\
\hline 6. & C6 & Hutang toko & $5 \%$ & Benefit \\
\hline 7. & C7 & $\begin{array}{l}\text { Status } \\
\text { kepegawaian }\end{array}$ & $5 \%$ & Benefit \\
\hline
\end{tabular}

Sumber: (Widyastuti, 2019)

Tabel 1. Tabel Sub Kriteria

\begin{tabular}{|c|c|c|}
\hline \multicolumn{3}{|c|}{ Jumlah Pinjaman } \\
\hline No. & Keterangan & Nilai \\
\hline 1. & $0-5 \mathrm{jt}$ & 1 \\
\hline 2. & $5 \mathrm{jt}-10 \mathrm{jt}$ & 2 \\
\hline 3. & $10 \mathrm{jt}-15 \mathrm{jt}$ & 3 \\
\hline 4. & $>15 \mathrm{jt}$ & 4 \\
\hline \multicolumn{3}{|c|}{ Gaji Bersih } \\
\hline No. & Keterangan & Nilai \\
\hline 1. & $1 \mathrm{jt}-3,5 \mathrm{jt}$ & 1 \\
\hline 2. & $3,5 \mathrm{jt}-5 \mathrm{jt}$ & 2 \\
\hline 3. & $5 j \mathrm{j}-10 \mathrm{jt}$ & 3 \\
\hline 4. & $>10 \mathrm{jt}$ & 4 \\
\hline \multicolumn{3}{|c|}{ Pinjaman Uang Kopkar } \\
\hline No. & Keterangan & Nilai \\
\hline 1. & $>3 \mathrm{jt}$ & 1 \\
\hline 2. & $2 \mathrm{jt}-3 \mathrm{jt}$ & 2 \\
\hline 3. & $1 \mathrm{jt}-2 \mathrm{jt}$ & 3 \\
\hline 4. & $0-1 \mathrm{jt}$ & 4 \\
\hline \multicolumn{3}{|c|}{ Pinjaman Barang Koperasi Karyawan } \\
\hline No. & Keterangan & Nilai \\
\hline 1. & $>3 \mathrm{jt}$ & 1 \\
\hline 2. & $2 j t-3 j t$ & 2 \\
\hline 3. & $1 \mathrm{jt}-2 \mathrm{jt}$ & 3 \\
\hline 4. & $0-1 \mathrm{jt}$ & 4 \\
\hline \multicolumn{3}{|c|}{ Pinjaman Bank } \\
\hline No. & Keterangan & Nilai \\
\hline 1. & $>3 \mathrm{jt}$ & 1 \\
\hline 2. & $2 \mathrm{jt}-3 \mathrm{jt}$ & 2 \\
\hline 3. & $1 \mathrm{jt}-2 \mathrm{jt}$ & 3 \\
\hline 4. & $0-1 \mathrm{jt}$ & 4 \\
\hline \multicolumn{3}{|c|}{ Hutang Toko } \\
\hline No. & Keterangan & Nilai \\
\hline 1. & $>500 \mathrm{rb}$ & 1 \\
\hline 2. & $300 \mathrm{rb}-500 \mathrm{rb}$ & 2 \\
\hline 3. & $100 \mathrm{rb}-300 \mathrm{rb}$ & 3 \\
\hline 4. & $0-100 \mathrm{rb}$ & 4 \\
\hline \multicolumn{3}{|c|}{ Status Kepegawaian } \\
\hline No. & Keterangan & Nilai \\
\hline 1. & Kontrak 1 -3thn & 1 \\
\hline 2. & Kontrak 4 - 7thn & 2 \\
\hline 3. & Kontrak >8thn & 3 \\
\hline 4. & Tetap & 4 \\
\hline
\end{tabular}

Sumber: (Widyastuti, 2019)

Berikut adalah hasil simulasi dari sample yang kami ambil untuk menentukan anggota yang dapat menerima pinjaman koperasi karyawan universitas mercu buana. Dalam Tabel 3. Dibawah ini, kami menjelaskan bagaimana meletakan matriks antara kriteria dengan alternative:

Tabel 2. Tabel Kasus

\begin{tabular}{lllll}
\hline \multirow{2}{*}{ Kriteria } & \multicolumn{4}{c}{ Alternatif } \\
\cline { 2 - 5 } & $\mathbf{A 1}$ & $\mathbf{A 2}$ & $\mathbf{A 3}$ & $\mathbf{A 4}$ \\
\hline $\begin{array}{l}\text { Jumlah } \\
\text { pinjaman }\end{array}$ & 5.000 .000 & 3.500 .000 & 7.000 .000 & 6.000 .000 \\
\hline Gaji bersih & 3.000 .000 & 3.000 .000 & 4.000 .000 & 3.000 .000 \\
\hline $\begin{array}{l}\text { Pinjaman } \\
\text { uang kopkar }\end{array}$ & 0 & 2.500 .000 & 0 & 0 \\
\hline $\begin{array}{l}\text { Pinjaman } \\
\text { barang }\end{array}$ & 0 & 0 & 0 & 500.000 \\
\hline
\end{tabular}

\begin{tabular}{lllll}
\hline kopkar & & & & \\
$\begin{array}{l}\text { Pinjaman } \\
\text { bank }\end{array}$ & 0 & 0 & 0 & 0 \\
\hline Hutang toko & 300.000 & 0 & 0 & 0 \\
\hline $\begin{array}{l}\text { Status } \\
\text { kepegawaian }\end{array}$ & Tetap & $\begin{array}{l}\text { Kontrak } \\
\text { 2thn }\end{array}$ & $\begin{array}{l}\text { Kontrak } \\
\text { 3thn }\end{array}$ & Tetap \\
\hline
\end{tabular}

Sumber : (Widyastuti, 2019)

Pada Tabel 3. disebutkan bahwa data sebenarnya dari tiap-tiap anggota yang mengajukan pinjaman pada koperasi karyawan disandingkan dengan penggolongan berdasarkan kriteria pengambilan keputusan.

Kemudian setelah didapatkan data sebenarnya dari tiap-tiap anggota yang mengajukan pinjaman, kami subsitusi datanya menggunakan nilai yang telah disediakan pada Tabel 2 diatas. Hasil pengisian tabel matrikulasi yang telah disubsitusi tersebutkami ilustrasikan dengan Tabel 4. di bawah ini:

Tabel 4. Tabel Alternatif pada setiap Kriteria

\begin{tabular}{lllll}
\hline \multirow{2}{*}{ Kriteria } & \multicolumn{4}{c}{ Alternatif } \\
\cline { 2 - 5 } & $\mathbf{A 1}$ & $\mathbf{A 2}$ & $\mathbf{A 3}$ & $\mathbf{A 4}$ \\
\hline C1 & 1 & 1 & 2 & 2 \\
\hline C2 & 1 & 1 & 2 & 1 \\
\hline C3 & 4 & 2 & 4 & 4 \\
\hline C4 & 4 & 4 & 4 & 4 \\
\hline C5 & 4 & 4 & 4 & 4 \\
\hline C6 & 3 & 4 & 4 & 4 \\
\hline C7 & 4 & 1 & 1 & 4 \\
\hline
\end{tabular}

Sumber: (Widyastuti, 2019)

1) Dari Tabel diatas kami membuatnormalisasi matriks keputusan dengan cara menghitung nilai rating kinerja ternomalisasi dari alternative pada kriteria berdasarkan rumus di bawah ini :

$$
r_{i}=\left\{\begin{array}{c}
\frac{x_{i j}}{M a x x_{i j}} \text { Jikajatributkeuntungan (benefit) } \\
\frac{M i n x_{i j}}{x_{i j}} \text { Jikajatributbiaya }(\text { cost })
\end{array}\right.
$$

Penilaian rating criteria akan kami contoh melalui baris C1.Dari baris C1 nilai maksimalnya yaitu 2.Maka hasil perhitungannya adalah :

$$
\begin{aligned}
& \mathrm{R} 11=\frac{1}{2}=0,5 \\
& \mathrm{R} 21=\frac{1}{2}=0,5 \\
& \mathrm{R} 31=\frac{2}{2}=1 \\
& \mathrm{R} 41=\frac{2}{2}=1
\end{aligned}
$$

Maka dapat disimpulkan hasil perhitungan nilai rating kinerja ternomalisasi dari alternatif pada kriteria yaitu : 


$$
R=\left[\begin{array}{cccc}
0,5 & 0,5 & 1 & 0,5 \\
0,5 & 0,5 & 1 & 0,5 \\
1 & 0,5 & 1 & 1 \\
1 & 1 & 1 & 1 \\
1 & 1 & 1 & 1 \\
0,75 & 1 & 1 & 1 \\
1 & 0,25 & 0,25 & 1
\end{array}\right]
$$

2) Setelah mendapatkan hasil dari normalisasi selanjutnya yaitu perangkingan dengan rumus dibawah ini:

$$
V_{i}=\sum_{j=1}^{n} W_{j} r_{i j}
$$

Tabel 3. Tabel Bobot Kriteria

\begin{tabular}{lll}
\hline No. & Kriteria & Nilai W \\
\hline 1. & C1 & 0,25 \\
\hline 2. & C2 & 0,3 \\
\hline 3. & C3 & 0,1 \\
\hline 4. & C4 & 0,1 \\
\hline 5. & C5 & 0,15 \\
\hline 6. & C6 & 0,05 \\
\hline 7. & C7 & 0,05 \\
\hline
\end{tabular}

Sumber: (Widyastuti, 2019)

\section{Perancangan Sistem}

\section{Use Case Diagram}

$\mathrm{V} 1=(0,25) \cdot(0,5)+(0,3) \cdot(0,5)+(0,1) \cdot(1)+(0,1) \cdot(1)+$ $(0,15) \cdot(1)+(0,05) \cdot(0,75)+(0,05) \cdot(1)=0,7125$ $\mathrm{V} 2=(0,25) \cdot(0,5)+(0,3) \cdot(0,5)+(0,1) \cdot(0,5)+$ $(0,1) \cdot(1)+(0,15) \cdot(1)+(0,05) \cdot(1)+(0,05) \cdot(0,25)=$ 0,6375

$\mathrm{V} 3=(0,25) \cdot(1)+(0,3) \cdot(1)+(0,1) \cdot(1)+(0,1) \cdot(1)+$ $(0,15) \cdot(1)+(0,05) \cdot(1)+(0,05) \cdot(0,25)=0,9625$

$\mathrm{V} 4=(0,25) \cdot(1)+(0,3) \cdot(0,5)+(0,1) \cdot(1)+(0,1) \cdot(1)+$ $(0,15) \cdot(1)+(0,05) \cdot(1)+(0,05) \cdot(1)=0,85$

Dari hasil perhitungan, berikut rekomendasi perangkingan anggota, dimana semakin mendekati angka 1, maka semakin memiliki resiko rendah tidak mampu untuk membayar yaitu:

Tabel 4. Tabel Hasil Perangkingan

\begin{tabular}{lllll}
\hline Rangking & Alternatif & Kode & Nilai & Status \\
\hline 1 & V3 & A3 & 0,9625 & Diterima \\
\hline 2 & V4 & A4 & 0,85 & Diterima \\
\hline 3 & V1 & A1 & 0,7125 & Diterima \\
\hline 4 & V2 & A2 & 0,6375 & Ditolak
\end{tabular}

Sumber: (Widyastuti, 2019)

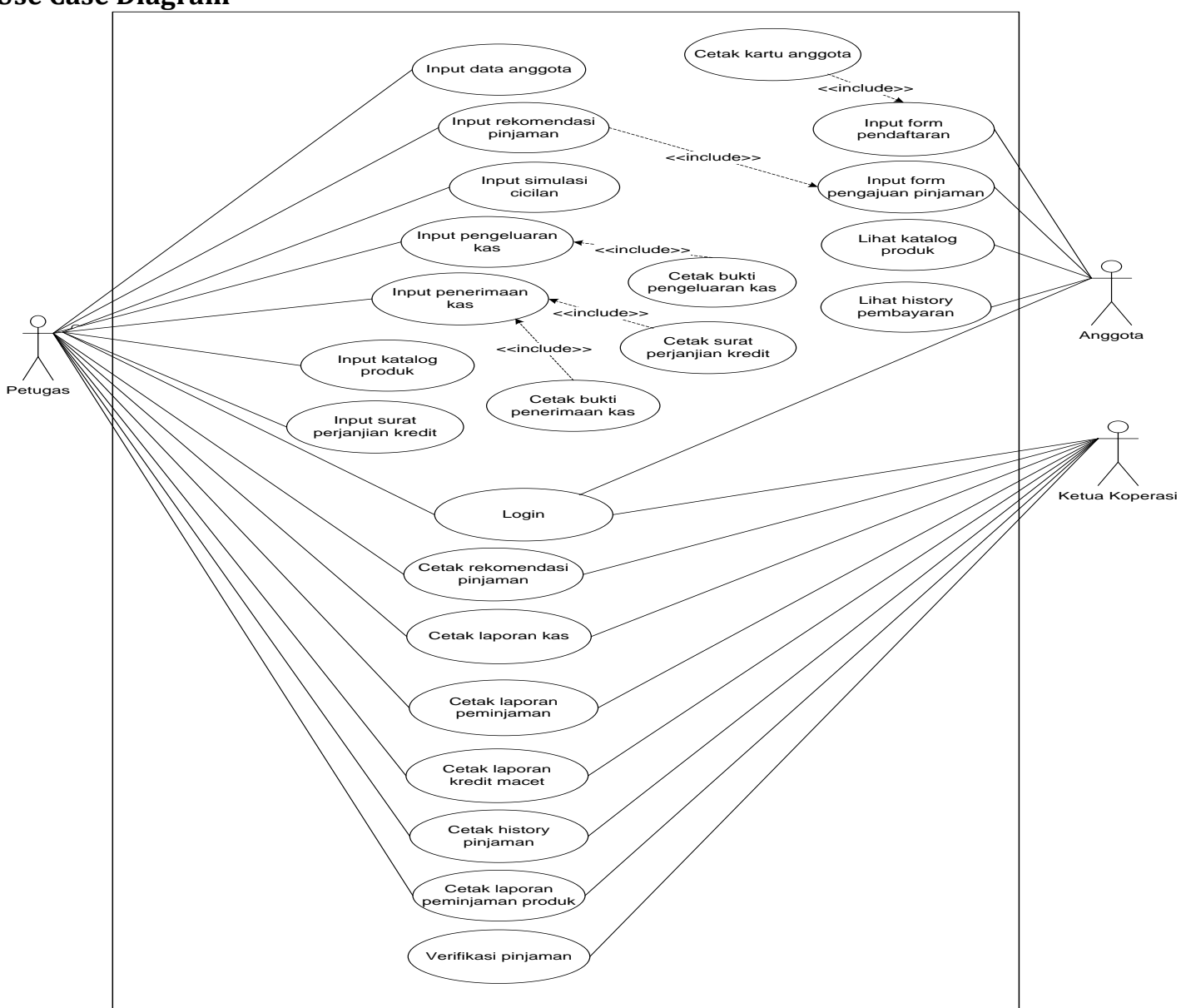

Sumber: (Widyastuti, 2019)

Gambar1. Use Case Diagram 


\section{Activity Diagram}

Adapun activity diagram yang menjelaskan prosedur proses bisnis berjalan yaitu berjumlah 23 activity, berikut kami lampirkan beberapa activity diagram usulan yang kami buat seperti pada gambar 2 dan 3 dibawah ini :

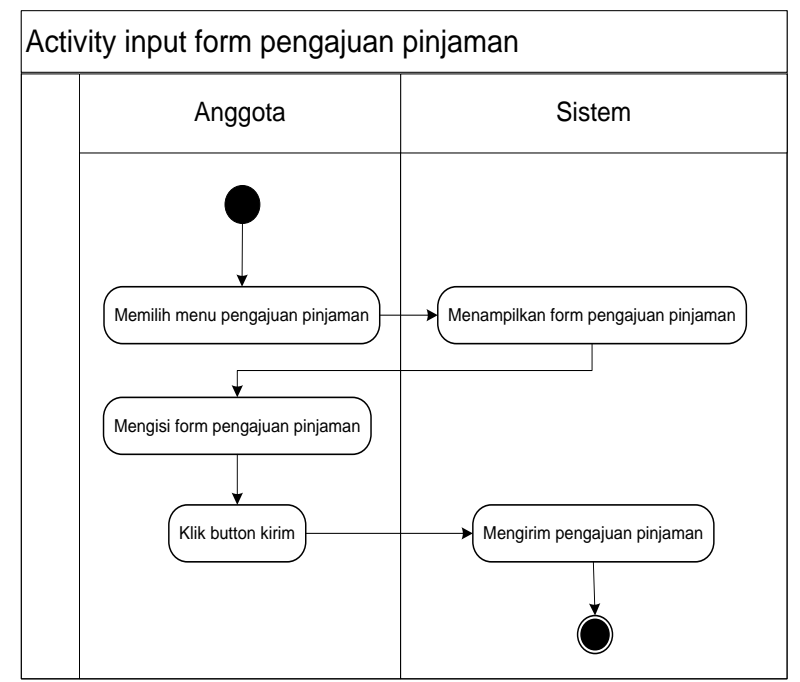

Sumber: (Widyastuti, 2019)

Gambar2. Activity Diagram Input Form Pengajuan Pinjaman

Berikut adalah penjelasan Activity Diagram Input Form Pengajuan Pinjaman :

a. Aktor memilih menu pengajuan pinjaman

b. Sistem menampilkan form pengajuan pinjaman

c. Aktor mengisi form pengajuan pinjaman

d. Aktor klik button kirim

e. Sistem mengirim pengajuan pinjaman

f. Proses selesai

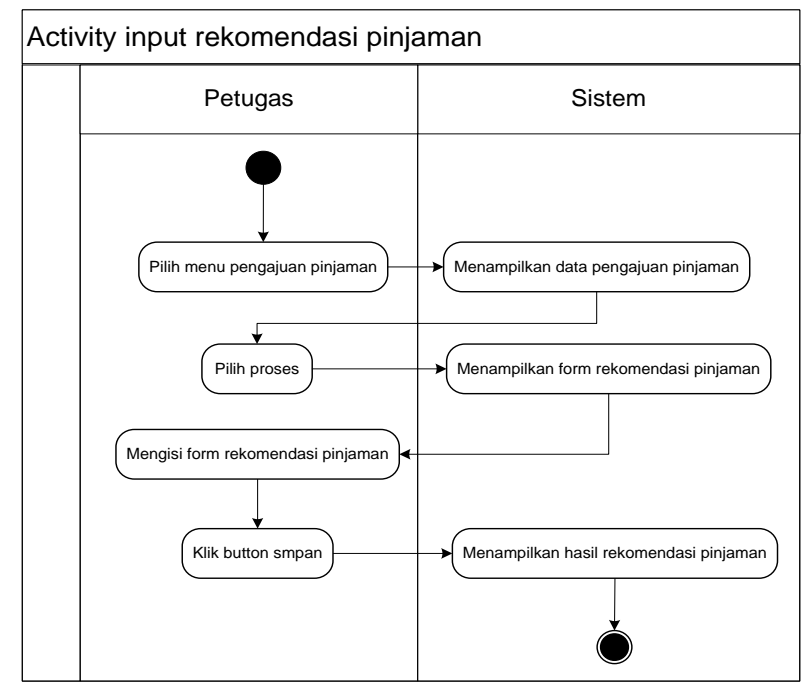

Sumber: (Widyastuti, 2019)

Gambar3. Activity Diagram Input Rekomendasi Pinjaman
Berikut adalah penjelasan Activity Diagram Input Rekomendasi Pinjaman:
a. Petugas memilih menu pengajuan pinjaman
b. Sistem menampilkan data pengajuan pinjaman
c. Petugas pilih proses
d. Sistem menampilkan form rekomendasi pinjaman
e. Petugas mengisi form rekomendasi pinjaman
f. Klik button simpan
g. Sistem menampilkan hasil rekomendasi pinjaman
h. Proses selesai

\section{Sequence Diagram}

Dalam pembuaan sequence diagram pada rancangan ini, kami memberi informasi diatas setiap object tentang klasifikasi apakah object tersebut actor, boundary, control atau entity. Berikut kami lampirkan beeberapa contoh sequence diagram yang kami buat pada gambar 4 dan 5 di bawah ini:

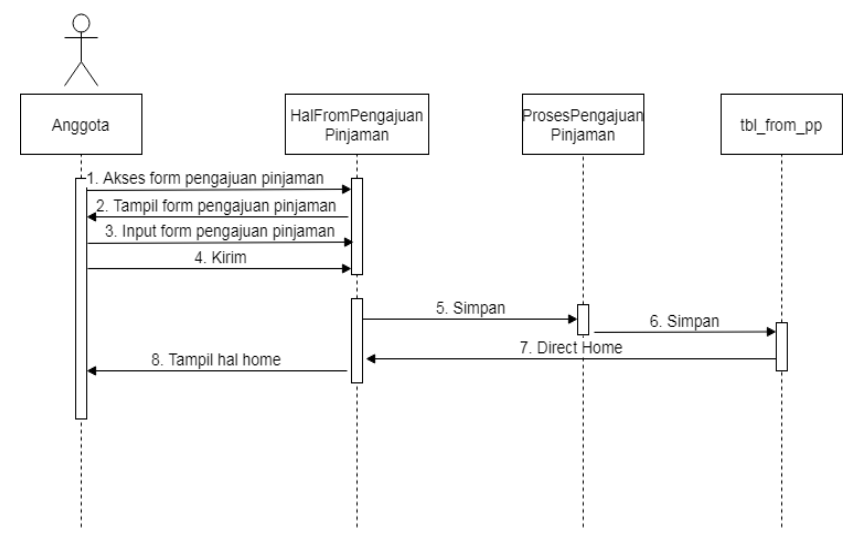

Sumber: (Widyastuti, 2019)

Gambar2. Sequence Diagram Input Form Pengajuan Pinjaman

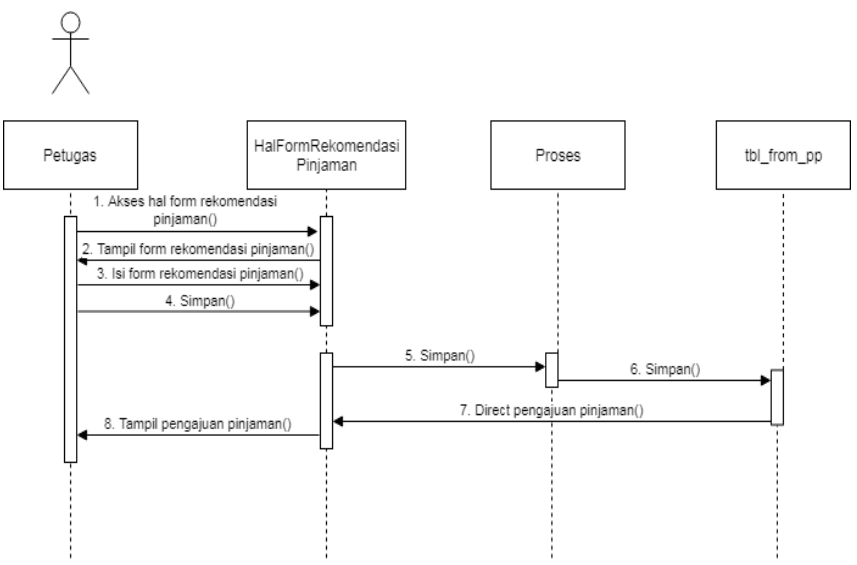

Sumber: (Widyastuti, 2019)

Gambar3. Sequence Diagram Input Rekomendasi Pinjaman 


\section{Class Diagram}

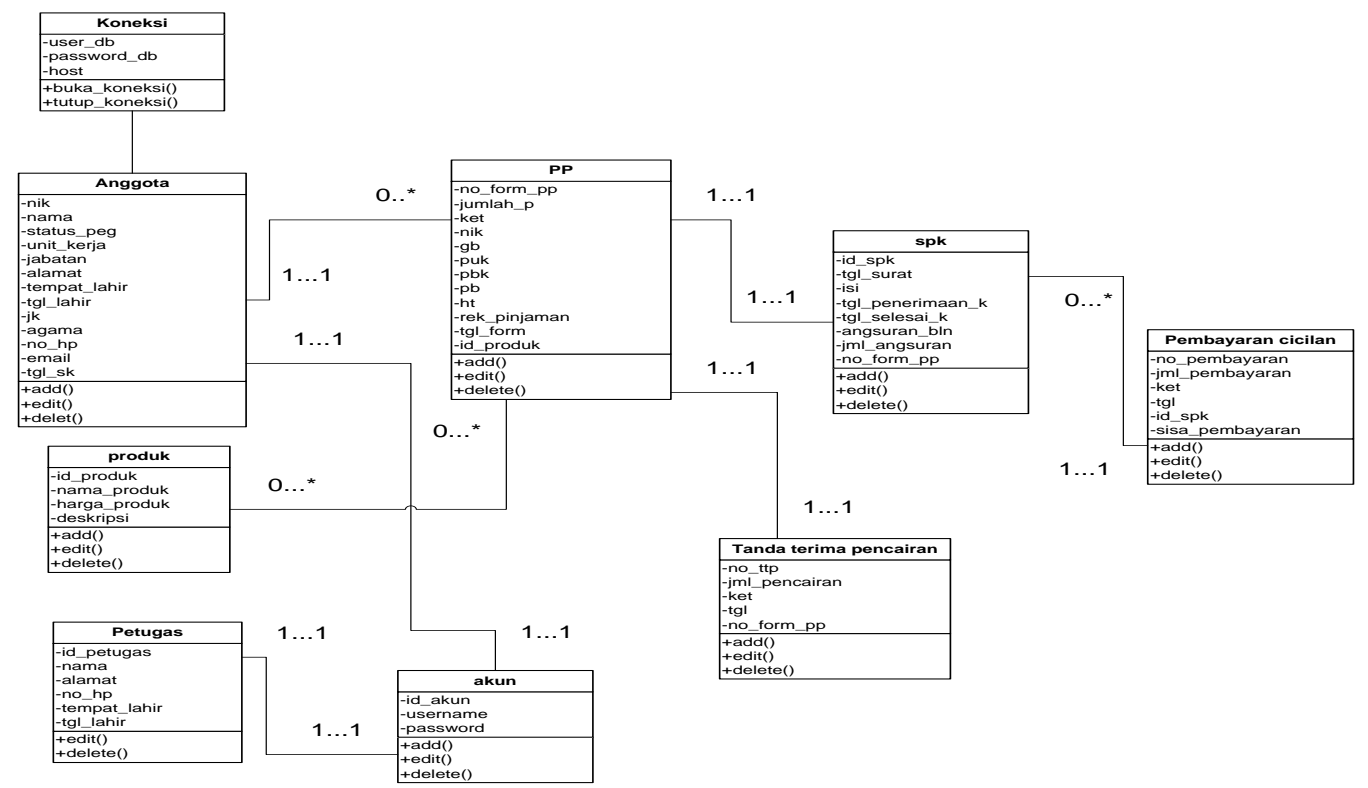

Sumber: (Widyastuti, 2019)

Gambar 6. Class Diagram

\section{Rancangan User Interface}

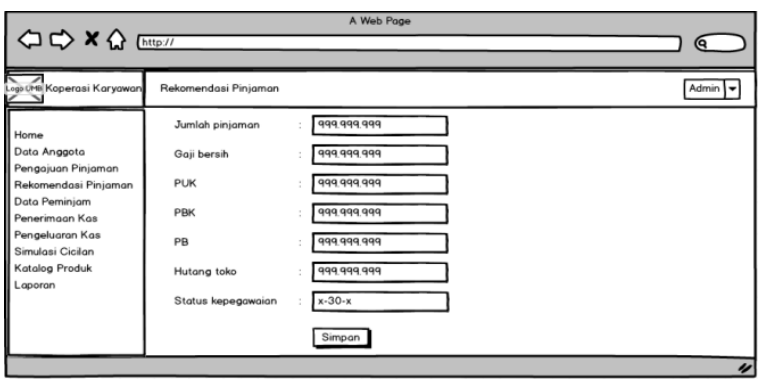

Sumber: (Widyastuti, 2019)

Gambar 7. Rancangan User Interface Form Rekomendasi Pinjaman

Rancangan ini adalah tampilan form untuk mengisi rekomendasi pinjaman yang akan menentukan diterima atau tidaknya pengajuan pinjaman.

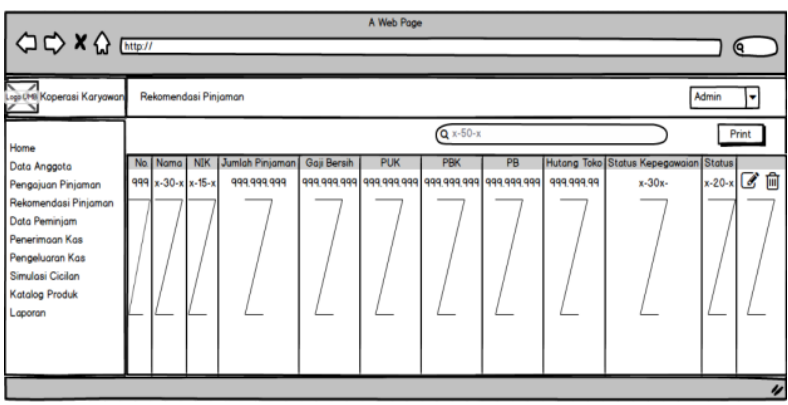

Sumber: (Widyastuti, 2019)

Gambar 8. Rancangan User Interface Data Rekomendasi Pinjaman
Rancangan ini adalah tampilan data hasil inputan dari rekomendasi pinjaman.

\section{KESIMPULAN}

Kesimpulan yang dapat diambil dari hasil analisa perancangan sistem informasi pengajuan pinjaman menggunakan metode SAW berbasis web studi kasus koperasi karyawan Universitas Mercu Buana, yaitu: adanya sistem pengambilan keputusan pada proses pengajuan pinjaman dapat memberikan kemudahan pada koperasi dalam menentukan penerima pinjaman. Adanya Sistem informasi dapat membantu dalam memanajemen data yang masuk.

\section{REFERENS}

Astuti, D., \& Devitra, J. (2017). Dui Astuti, Joni Devitra. Jurnal Manajemen Sistem Informasi, 2(2), 513-532.

Christin, H. De, Djamain, Y., Informatika, J. T., \& Informatika, J. T. (2015). Sistem Pendukung Keputusan Penerimaan Pegawai Baru PT.PLN (Persero) Kantor Pusat dengan Menggunakan Metode Simple Additive Weighting (SAW). Jurnal Teknologi Dan Informasi, 5(1), 39-47.

Journal, C., Utomo, Y. B., \& Ipmawati, J. (2016). Sistem Pendukung Keputusan Penentuan 
Penerima Kredit Usaha ( Studi Kasus : Adira Finance Kediri ). Citec Journal, 3(4), 295306.

Rudiarto, S. (2018). IMPLEMENTASI ALGORITMA K-MEANS. Jurnal Ilmu Teknik Dan Komputer, 2(1), 1-8.

Saw, D. M. (2019). Penyeleksian jurusan terfavorit pada smk sirajul falah dengan metode saw. Jurnal PILAR Nusa Mandiri, 15(1), 1-6.

Subiantara, D., Sulistiowati, \& Vivine, N. (2015). RANCANG BANGUN APLIKASI SIMPAN PINJAM ISSN 2338-137X. Jurnal Sistem Informasi Dan Komputerisasi Akuntansi, 4(2), 1-8.

Waluya, D., \& Dimas, F. (2017). Perancangan Sistem Informasi Akuntansi Koperasi dan UMKM Berbasis. Jurnal Riset Akuntansi Dan Keuangan, 5(2), 1423-1440.

Wati, Y. A., \& Sadikin, M. (2019). KEPUTUSAN PRIORITAS PERBAIKAN MOLD MENGGUNAKAN METODE SAW ( SIMPLE ADDITIVE WEIGHTING ). Jurnal Ilmu Teknik Dan Komputer, 3(1), 1-10.

Widyastuti, T. (2019). Laporan Akhir Penelitian Analisa Perancangan Sistem Informasi Pengajuan Pinjaman Menggunakan Metode Simple Additive Weighting (Studi Kasus: Koperasi Karyawan Universitas Mercu Buana). Jakarta. 